\title{
NMR Imaging for Measuring Root System and Soil Water Content
}

\author{
Kenji Omasa, Morio OnoE* and Hiroaki Yamada* \\ Division of Engineering, The National Institute for Environmental Studies, \\ Yatabe, Ibaraki 305, Japan \\ *Institute of Industrial Science, University of Tokyo, \\ Roppongi, Tokyo 106, Japan
}

(Received December 21, 1985)

\begin{abstract}
An attempt was made using a nuclear magnetic resonance (NMR) computed tomography (CT) system to measure spatial distributions of soil water and main roots of broad bean and Japanese radish plants growing in the soil without destroying the plants and the soil environment.
\end{abstract}

Computed tomography $(\mathrm{CT})$ is a technique to reconstruct from a set of projection data a cross-sectional distribution of some physical property of a test object without destroying it. This technique has been widely utilized in medicine and industry since the first development of a commercial X-ray CT scanner by Hounsfield. ${ }^{1)}$ Recently, the X-ray CT scanner was applied to detect rots and annual rings in a living tree. ${ }^{2)}$

Nuclear magnetic resonance (NMR) CT is the newest technique in the medical CT family..$^{3-5)}$ It yields not only morphological information but also such physiological information as metabolic process and mass transfer. Especially, the distribution of proton, which is abundant in water, in any section is easily provided by the NMR CT.4,5)

In order to study the growth of seedling and root system it is necessary to measure them without destroying the plant itself and the soil environment. Rhizotrons are the most elaborate installation devised for the direct, sustained observation and measurement of roots growing in soil. ${ }^{6)}$ However, rhizotrons permit observation only through transparent walls or windows abutting on the soil. Gordon et al. ${ }^{7)}$ recently observed a sunflower seedling growing in a rectangular cuvette containing 1\% agar using a TV camera system. However, this system cannot directly observe seedling and root growing in soil.

The growth of seedling and root system is greatly influenced by the soil environment. ${ }^{8}$ ) The soil moisture is a major factor affecting the growth. The common methods for measuring soil water content are neutron probes and capacitance meters. Electrical resistance blocks and tensiometers can also be used to estimate soil water content as well as matric potential. ${ }^{8)}$ However, these devices affect the growth of root system and cannot measure spatial distribution of water in soil abutting on the spreading roots.

We, therefore, examined NMR imaging for measuring water content of soil and root systems growing in a pot. Broad bean (Vicia fava L. cv. Otafuku) and Japanese radish (Raphanus sativus L. cv. Minowase) plants were used. Broad 

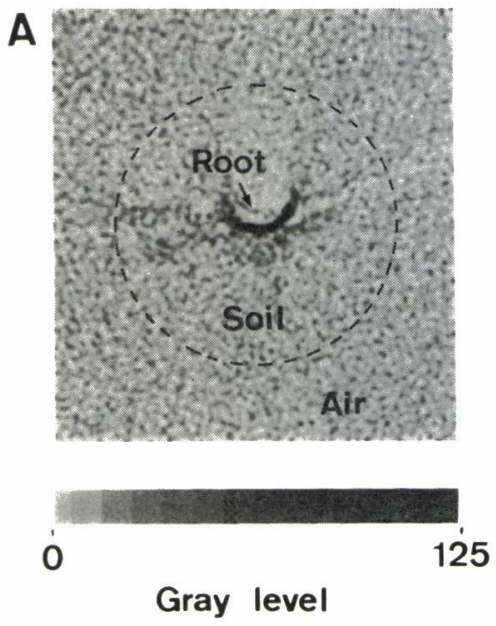
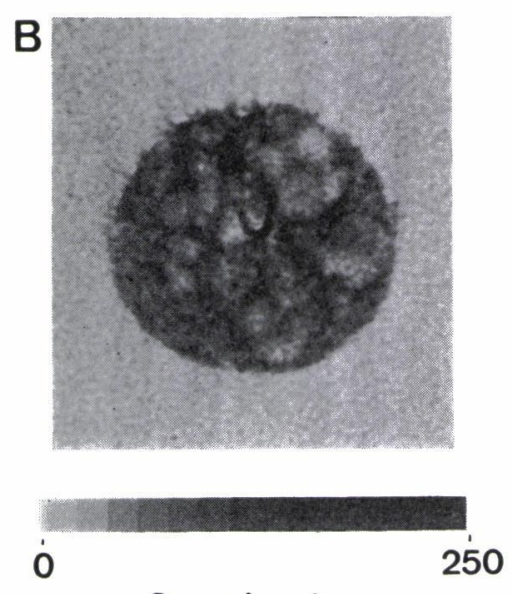

Gray level

Fig. 1 NMR images of dry and wet soils with broad bean roots in horizontal sections of pots. A, air-dried soil; B, wet soil. The gray level indicating with numerals under the gray scale means the intensity of NMR signal.

bean was grown in a pot $(10 \mathrm{~cm}$ in diameter and $20 \mathrm{~cm}$ in height $)$ in a controlledenvironment greenhouse at $20 / 15^{\circ} \mathrm{C}$ day/night temperature and $70 \% \mathrm{RH}$ (Relative humidity) under natural lighting for 2 to 3 weeks. Radish was grown at $25 / 20^{\circ} \mathrm{C}$ day/night temperature and $70 \% \mathrm{RH}$ for 4 to 5 weeks. The pot was filled with a $1: 1(\mathrm{v} / \mathrm{v})$ mixture of perlite and peat moss. The saturation recovery (SR) image in any section of the pot was measured by an NMR CT system (Toshiba, Model MRT-15A). This system had magnet coils of $0.15 \mathrm{~T}$ in the intensity of the basic magnetic field and of $400 \mathrm{~Hz} / \mathrm{cm}$ (center frequency; $6.39 \mathrm{MHz}$ ) in the spatial gradient of the magnetic field. The reconstructed matrix of this CT system was $512(\mathrm{H}) \times 512(\mathrm{~V})$ and the spatial resolution was within $2 \mathrm{~mm}$. The repetition time for obtaining the SR image was $525 \mathrm{~ms}$. Air temperature and humidity in a space $(60 \mathrm{~cm}$ in diameter and $120 \mathrm{~cm}$ in length) setting the pot in the NMR scanner were maintained at $25^{\circ} \mathrm{C}$ and $60 \% \mathrm{RH}$.

Figure 1 shows NMR images of dry and wet soils with broad bean roots in horizontal sections of pots. The gray level indicated by the numerals under the gray scale shows the intensity of NMR signal. NMR signal from air-dried soil (ca. pF 5.5) in A was very weak except that from the root in the center, and the background noise was observed as black-and-white spots. Therefore, we could not separate the soil from the surrounding air. The wet soil (ca. pF 2) in $\mathrm{B}$ showed high gray level although the level differed from region to region in the pot. Since the bulk of protons in soil is water, the gray level represents its water content.

Figure 2 shows an NMR image of a broad bean and its main root in a vertical section of a pot with wet soil. Since the gray level of the bean and root was higher than that of soil, we could easily discriminate the bean and its main root from the soil. However, roots finer than $2 \mathrm{~mm}$ could not be seen by this CT system. The ununiformity in the soil water content was probably influenced by the water uptake of roots as well as by the spatial distribution of soil struc- 


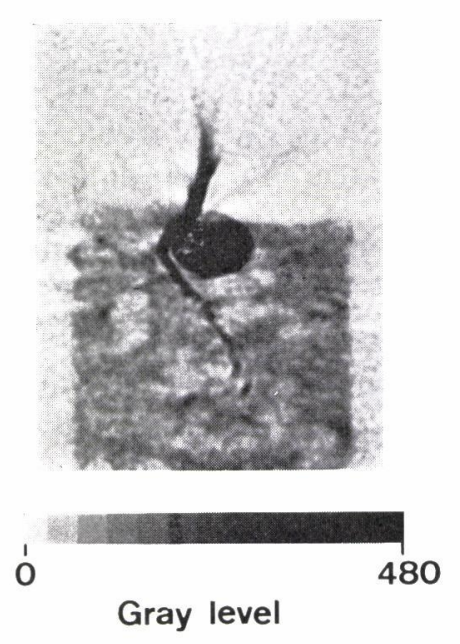

Fig. 2 NMR image of a broad bean and its main root in a vertical section of a pot with wet soil.

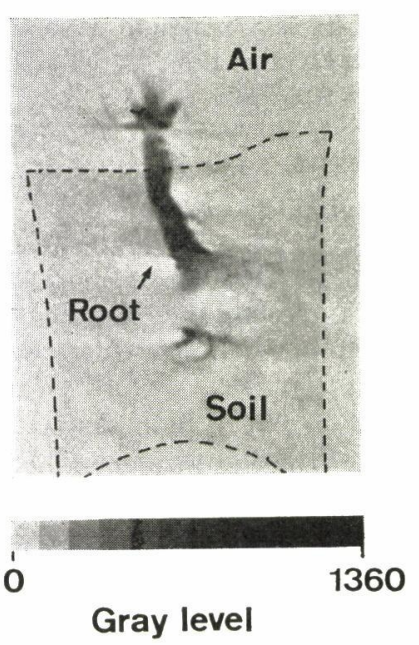

Fig. 3 NMR image of a main root of Japanese radish with the injury in a vertical section of a pot with wet soil.

ture. Figure 3 shows an NMR image of a main root of Japanese radish in a pot with wet soil. When the gray scale extended to wide level, we could detect the ununiformity in the root in addition to that in the soil. This ununiformity may be caused by the unknown injury.

The results suggest that the NMR imaging is an effective method for measuring spatial distributions of water in soil and roots growing in the soil. By analyzing the image the information about the growth in seedling and root and the water uptake of root may be provided without destroying the plant itself and the soil environment. Since NMR signal, especially transverse relaxation time $\left(T_{2}\right)$, relates to water potential as well as water content in plants, ${ }^{9,10)}$ the $\mathrm{CT}$ system also may used to measure spatial distributions of water potential. Although the CT system used in the experiment could not detect roots finer than $2 \mathrm{~mm}$, this problem will be improved by increasing the gradient of magnetic field and the sampling density. NMR CT is more suitable for making threedimensional image in comparison with X-ray CT.

We wish to thank Messrs. H. Goshima and K. Kitadate of Toshiba Co. for the use of a NMR CT system.

\section{REFERENCES}

1) Hounsfield, G. N. 1973. Computerized transverse axial scanning: Part I, Description of system. Brit. J. Radio. 46: 1016-1022.

2) Onoe, M., J. W. Tsao, H. Yamada, H. Nakamura, J. Kogure, H. Kawamura, and M. Yoshimatsu. 1983. Computed tomography for measuring annual rings of a live tree. Proc. IEEE. 71: 907-908.

3) LAUterber, P. C. 1973. Image formation by induced local interactions-examples em- 
ploying nuclear magnetic resonance. Nature 242: 190-191.

4) MANSFIELD, P. 1976. Proton spin imaging by nuclear magnetic resonance. Contemp. Phys. 17: 553-576.

5) PyкeTt, I. L. 1982. NMR imaging in medicine. Sci. Am. 246 (5): 54-64.

6) HUCK, M. G., and H. M. TAYLOR. 1982. The rhizotron as a tool for root research. Adv. Agron. 35: 1-35.

7) Gordon, D. C., I. R. Macdonald, J. W. Hart, and A. Berg. 1984. Image analysis of geo-induced inhibition, compression, and promotion of growth in an inverted Helianthus annuus L. seedling. Plant Physiol. 76: 589-594.

8) Kramer, P. J. 1983. Water Relations of Plants. 84-119. Academic Press, New York.

9) VAN As, H. 1982. “NMR, Water and Plants,” Ph.D. thesis, 1-133. Wageningen.

10) Van As, H., T. J. SchaAfSma, and J. BlaAkmear. 1986. Application of NMR to water flow and balances in plants. Acta Horticulturae 174 (in press).

〈和文抄録〉

\section{根系と土歵水分の測定のための NMR イメージング \\ 大政謙次・尾上守夫*・山田博章* \\ 国立公害研究所技術部, *東京大学生産技術研究所}

NMR-CT を用いて，ポット栽培の植物（ソラ豆, 大根）の根系と土壌水分の非破壊計測を試みた. 最初に, SR 法で得た NMR 信号の強度と土塞水分との関係を調べたところ, 風乾土塨では信号強度が 非常に小さく，ノイズレベルにあったが，土塞が湿ると大きくなった．しかし，その空間分布は，不均 一であった．次に十分に湿った土堙中での根系の分布を計測したが，根からの信号強度は土䁃に比べて 十分大きく，実験に用いた CT の解像度の範囲内ではあるが，土壌と根を容易に分離することができ た。 なた，根系の障害部位は，信号強度が小さく，CT を根の障害診断に用いることができることがわ かった。 